\title{
Influence of Climatic Seasonality on a Survey of Land Use and Cover in the Semi-arid Region
}

\author{
Anthony Rafael Soares Maia ${ }^{1}$, Fernando Bezerra Lopes ${ }^{2} \&$ Eunice Maia de Andrade ${ }^{2}$ \\ ${ }^{1}$ Water Management Company-COGERH, Fortaleza, Ceará, Brazil \\ ${ }^{2}$ Department of Agricultural Engineering, Federal University of Ceará, Fortaleza, Ceará, Brazil \\ Correspondence: Anthony Rafael Soares Maia, Water Management Company-COGERH, Rua Adualdo Batista, \\ 1550, Parque Iracema, Fortaleza, Ceará, CEP: 60.824.140, Brazil. E-mail: anthonyrafael.maia@cogerh.com.br
}

\author{
Received: July 6, $2018 \quad$ Accepted: August 19, $2018 \quad$ Online Published: October 15, 2018 \\ doi:10.5539/jas.v10n11p311 URL: https://doi.org/10.5539/jas.v10n11p311
}

\begin{abstract}
The dynamics of land use and land cover in watersheds of the Brazilian semi-arid region is not only influenced by human action, but also by the climatic seasonality of the region. Knowledge of the relationship between surveys of land use and land cover using geotechnology and the climatic seasonality of semi-arid regions is necessary. The aim of this study was to map and classify land use and cover in the watershed of the Orós reservoir (WSOR) with the help of geotechnology, and to identify the influence exerted by the climate on variations in the area of each class. The survey of land use and cover was carried out by means of the MAXVER method of classification of images from 2003, 2005, 2008 and 2013 from the LANDSAT 5 and LANDSAT 8 satellites. The areas of each class displayed dynamics influenced not only by human action but also by such factors as climate, topography and plant physiology. Years with high rainfall favoured classes such as thin scrub and dense scrub, with the opposite being seen in years considered as dry, when there was a considerable increase in areas of the anthropogenic class. Changes in the areas are caused by alterations in the deciduous vegetation; with leaf-fall during the dry season, these areas come to have the spectral response of areas with similar characteristics to the anthropogenic class. More-elevated regions favoured the presence of the dense-scrub class due to the microclimate and to the greater difficulty such areas present to human action.
\end{abstract}

Keywords: mapping, semi-arid region, geotechnology, climatic seasonality, land use and cover

\section{Introduction}

The conditions of forest cover are under constant change that may be subtle or abrupt, the result of both natural and anthropogenic forces (Hayes \& Cohen, 2007). The seasonality of regions with a tropical semi-arid climate and two well-defined seasons, one dry and one rainy, results in major changes in the landscape of dry forests. Such changes are due to the poor distribution of rainfall during the year, where different rainfall indices are seen for the two main seasons, dry and rainy, resulting in a rapid response to environmental change (Batista \& Santos, 2013).

In this way, climate is seen as the conditioning element of environmental dynamics, since it exerts a direct influence on both physical and biological processes (Silva et al., 2010). Verbesselt (2010) states that changes in ecosystems can be divided into three classes: (1) seasonal change, driven by the interaction of annual temperatures and precipitation impacting on plant phenology; (2) gradual change, such as interannual climate variability, a gradual change in land management or land degradation; and (3) abrupt change, caused by such disturbances as deforestation, urbanisation, floods and fires.

With regard to changes in ecosystems, it should be noted that the association between population growth and the development model adopted in the semi-arid region of Brazil has resulted in an increase in the pressure on natural resources due to changes in land use and cover in the region. Studies have demonstrated the negative impact that the degradation occurring over the years in the semi-arid region causes to the Caatinga Biome (Coelho et al., 2014; Pereira Filho, Silva, \& CÉzar, 2013; Silva, Lima, \& Mendonça, 2014; Vieira et al., 2013).

Activities such as deforestation for timber and the inclusion of new agricultural areas, intensive agriculture, overgrazing by livestock, and the expansion of urban areas, are examples of human intervention, which when carried out in a disorderly fashion result in degradation of the Caatinga. Such action has a negative effect on the 
whole environment, such as the destruction of biodiversity, soil degradation and erosion, flooding, and the silting of bodies of water, among others.

In view of the above, environmental monitoring aims to analyse the relevant aspects that allow the characterisation of changes occurring in land use and land cover, making it possible to evaluate the effects of human activity on ecosystems (Bertossi et al., 2013). However, analysing possible changes in the landscape and their impact is a complex task, and it is increasingly important to develop research that accurately measures the extent of such changes (Galharte et al., 2014).

Thus, the use of watershed as a planning unit seeks to achieve the effectiveness of integrating a set of soil and water management practices with a view to maintaining the balance of environmental resources, so as to provide adequate and sustainable development of all activities in the watershed (Frota, 2012). In this sense, the development of applied research on changes in land use and land cover of watersheds in semi-arid regions will increase the understanding of all factors that directly or indirectly influence these changes.

The aim of this study therefore, was to identify and classify types of land use and land cover in the watershed of the Orós reservoir, as well as to identify and analyse the influence that the climatic seasonality of the region exerts on these classes.

\section{Material and Methods}

\subsection{Geographical Location and General Characterisation}

The study area corresponds to the watershed of the Orós reservoir (WSOR), located in the semi-arid region of the State of Ceará, more specifically, in the south-west of the State (Figure 1). It is limited to the west by the State of Piauí; to the east by the Salgado Basin; to the north by the hinterland areas of Crateús, Banabuiú and the Middle Jaguaribe; and to the south by the State of Pernambuco. The WSOR drains an area of $24,900 \mathrm{~km}^{2}$, being completely inserted in the Upper Jaguaribe Basin, the largest in the state.

The climate of the region according to the Köppen classification is BSw'h', hot semi-arid with rainfall in the summer and autumn and average monthly temperature always above $18{ }^{\circ} \mathrm{C}$. The average rainfall for the watershed during the study period (2003, 2005, 2008 and 2013) was $635 \mathrm{~mm}$.

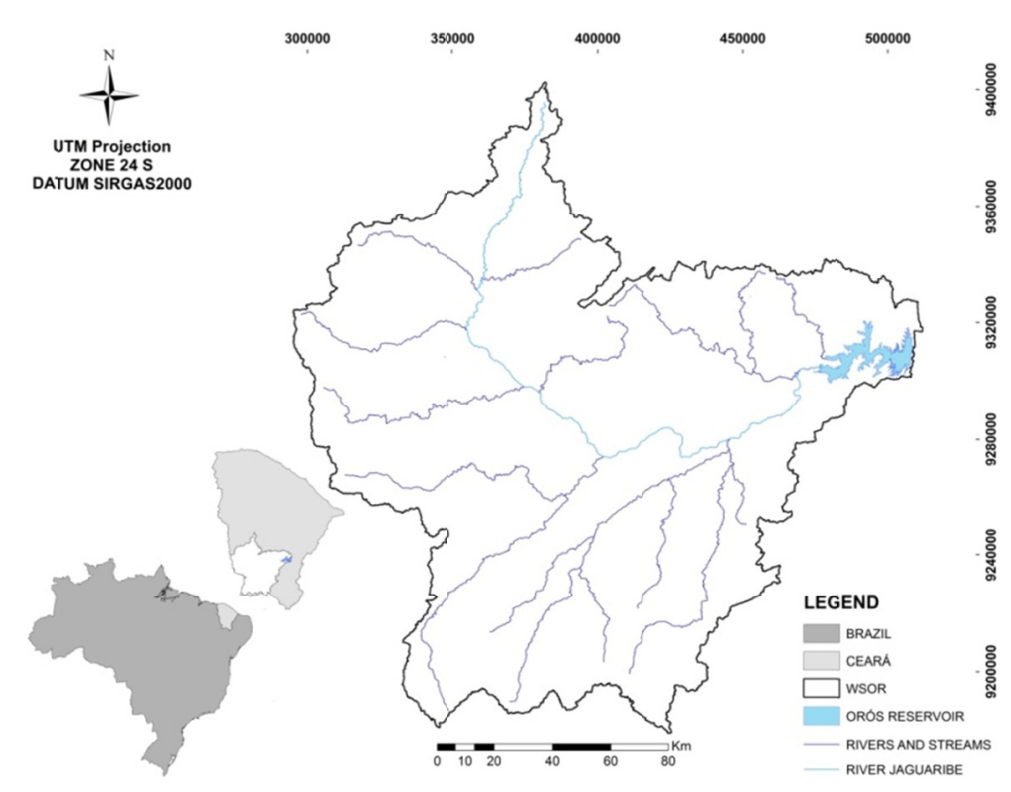

Figure 1. Location of the Orós watershed and main drainage network

The predominant natural vegetation in the WSOR is caatinga, formed by tree, shrub and herbaceous species. This type of vegetation has xerophytic characteristics, with small leaves, and may have a wax coating (Toledo, 2013).

The hydrographic network of the WSOR is composed of intermittent or ephemeral rivers, the main one being the River Jaguaribe, whose source is in the Joaninha Mountains, in the town of Tauá, and which flows $370 \mathrm{~km}$ to the 
Orós reservoir (Toledo, 2013). The Orós reservoir is the largest in the river basin and the second largest in the state, with a capacity of $1,940 \mathrm{hm}^{3}$, and a watershed of $202.11 \mathrm{~km}^{2}$ (Cogerh, 2015).

The terrain of the WSOR features plateaus and tablelands as well as depressions. The highest altitudes in the basin corresponds to two geomorphological units in the area: the Sertanejo Plateau, where the Araripe Plateau is inserted (in the south of the basin), and residual plateaus that are formed by ridges remaining inside the basin (Lopes, 2013). From SRTM data, it was possible to verify the elevation of the region as varying from 183 to 951 metres.

\subsection{Remote Sensing Data}

Images were used from the Landsat 5-TM and Landsat 8-OLI satellites, acquired from the Image Generating Division (DGI) of the National Institute for Space Research (INPE), and from the United States Geological Survey (USGS) respectively. To cover the entire area of the WSOR, it was necessary to obtain scenes from orbits 217 and 218 , points 64 and 65.

Due to the high availability of images, selection criteria were adopted, where the selected images should preferably have the least possible cloud cover, and have been produced in the second half of the year to minimise the effect of rainfall on vegetation in the region.

However, it was not possible to obtain all the scenes free of clouds, and it was necessary during the post-classification process to quantify the clouds as well as any shadows they caused.

In order to identify the effect of rainfall occurring during the previous months on image classification, total rainfall was calculated for each of the three months preceding those in which the images were generated. For the period of the study, 2005 stands out for having no rainfall during any of the months surveyed. Table 1 shows the total rainfall for each month, highlighting in bold type the month in which the images were generated.

Table 1. Rainfall behaviour in the three months prior to the month the images were obtained

\begin{tabular}{|c|c|c|c|c|c|c|c|}
\hline \multicolumn{2}{|c|}{2003} & \multicolumn{2}{|c|}{2005} & \multicolumn{2}{|c|}{2008} & \multicolumn{2}{|c|}{2013} \\
\hline Month & $\mathbf{m m}$ & Month & Mm & Month & Mm & Month & $\mathbf{m m}$ \\
\hline July & 0.00 & July & 0.00 & May & 70.16 & June & 49.69 \\
\hline August & 1.14 & August & 0.00 & June & 1.86 & July & 21.44 \\
\hline September & 0.00 & September & 0.00 & July & 4.36 & August & 3.86 \\
\hline October & 0.00 & October & 0.00 & August & 1.74 & September & 0.00 \\
\hline
\end{tabular}

Considering the above, the flowchart shown in Figure 2 illustrates the method adopted in producing the land use and cover maps for the WSOR.

Atmospheric correction of the images from the Landsat 5 satellite was carried out first. The atmospheric correction of satellite images allows characteristic reflectance values for the target to be obtained (Antunes et al., 2003). To do this, the X-6Scorr software was used (Montanher \& Paulo, 2014). The X-6SCorr software is based on $6 \mathrm{~S}$ computer code. This software converts digital numbers into apparent and surface bi-directional reflectance factors semi-automatically (Montanhe \& Paulo, 2014). 


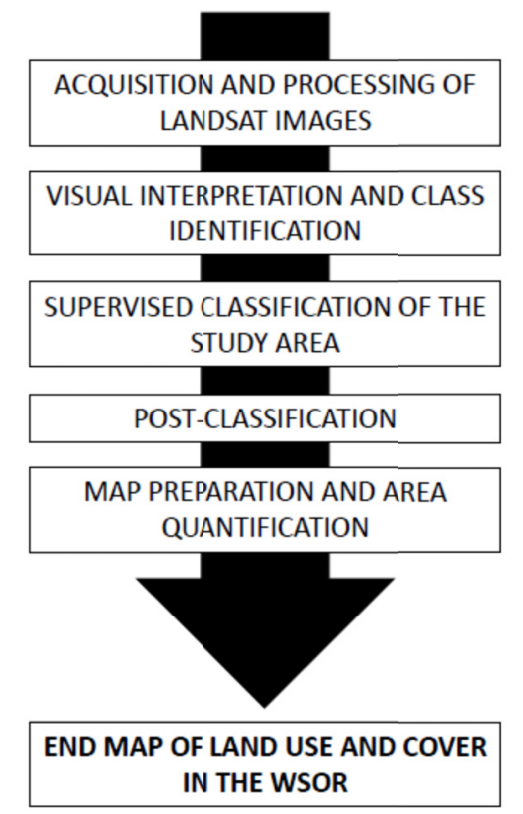

Figure 2. Flowchart adopted for elaborating the land use and cover maps

The next step included band combination. The combination chosen for the sensor images of the Landsat 5-TM satellite was R4/G3/B2 (false color), as it gives better definition of the limits between land and water, as well as showing differences in vegetation (INPE, 2014). The combination for the images of the Landsat 8-OLI satellite sensor was R5/G4/B3, as this covers almost the same wavelengths as the sensor bands of the Landsat 5 satellite, thereby giving the same results.

After band combination for all the scenes, the images were reprojected for the SIRGAS 2000 datum. Georeferencing of the images was then carried out, using Geocover 2000 images as reference. This step was performed only on the Landsat 5 images, since the Landsat 8 images are made available already georeferenced.

The next steps consisted of mosaic and clipping. The mosaic comprised assembly of the four scenes that cover the WSOR into a single scene. The aim of mosaic clipping was to select only that area of interest to the study; this step was carried out based on the shapefile containing the boundaries of the WSOR.

\subsection{Supervised Classification of Land Use and Land Cover}

For the survey of land use and cover in the WSOR, the MAXVER maximum likelihood supervised classification method was used. In order to obtain a satisfactory result using this method, a considerable number of pixels for the training samples must be selected.

In order to understand the dynamics occurring in the WSOR, the classes of land use and land cover chosen were: Water - comprising the hydrographic network, lakes and reservoirs present in the watershed; Anthropogenic Area-including areas characterised by urban occupation (buildings, road systems, etc.), deforested areas, exposed soil and areas of rainfed farming activities; Dense Scrub - representing the most dense form of tree-like plants; Thin Scrub-represented by low to medium size vegetation, characterised as shrub-like herbaceous caatinga; Riparian Forest - composed of vegetation found along the margins of rivers and reservoirs in the basin; Temporary Wetland - characterised by agricultural activities carried out in strips of land located within the watershed of the reservoir; Cloud; and Shadow.

The areas of riparian forest were defined according to Law 12,651 of 25 May 2012, which establishes a minimum width for the APP (Areas of Permanent Preservation) along the river course. To obtain the width of the rivers, the Google Earth software was used, where width measurements were made along the selected courses from the source of the river to its mouth; the average width of each course was then calculated. It should be noted that this average serves as a reference, as the width of the strip along the edge of the courses and the areas of permanent preservation are variable. 
To evaluate the quality and precision of the classifications, the accuracy and Kappa index were used, both obtained from the confusion matrix generated with the ENVI 4.7 software.

The Kappa index is used to validate image classifications made using remote sensing techniques. Table 2 identifies the values and quality level of the classification carried out as per Landis and Koch (1977).

Table 2. Quality of classification according to the Kappa index

\begin{tabular}{ll}
\hline Values for Kappa & Quality of classification \\
\hline$<0.00$ & Poor \\
$0.00-0.20$ & Bad \\
$0.21-0.40$ & Fair \\
$0.41-0.60$ & Good \\
$0.61-0.80$ & Very good \\
$0.81-1.00$ & Excellent \\
\hline
\end{tabular}

Source: Prepared by the author.

After classification of the images, the raster files containing information on the classes of land use and cover in the basin were transformed into vectors. These vectors were then converted into shapefiles, so that the area of each class could then be calculated using the ArcMap 9.3 software. Four shapefiles were obtained, containing complete information of the areas of each class of use and cover in the WSOR for the years under analysis. All the information from the areas was exported to spreadsheets to be quantified.

\section{Results and Discussion}

\subsection{Climatic Seasonality in the WSOR}

The rainfall of the region for the years under study (2003, 2005, 2008 and 2013) ranged from $453 \mathrm{~mm}$ to 932 $\mathrm{mm}$, with an average of $635 \mathrm{~mm}$. Table 3 shows the total annual rainfall, total rainfall during the rainy season (January to May), and the percentage of total rainfall in the watershed during the rainy season, for each year considered in the study. The rainy season mentioned above refers to the period of predominantly more rains in the study area, which includes January, February, March, April and May.

Table 3. Values for total annual rainfall, total rainfall during the rainy season, and percentage of total incident rainfall during the rainy season in the WSOR

\begin{tabular}{lllll}
\hline Year & $\mathbf{2 0 0 3}$ & $\mathbf{2 0 0 5}$ & $\mathbf{2 0 0 8}$ & $\mathbf{2 0 1 3}$ \\
\hline Total annual $(\mathrm{mm})$ & 618 & 535 & 932 & 453 \\
Total for rainy season $(\mathrm{mm})$ & 581 & 452 & 891 & 320 \\
Incident rainfall during the rainy season $(\%)$ & $94 \%$ & $84 \%$ & $96 \%$ & $71 \%$ \\
\hline
\end{tabular}

Source: Prepared by the author.

Analysing this information it is clear that a large part (at least 71\%) of the annual rainfall depth in the watershed for all the years surveyed is concentrated from January to May (rainy season). It is worth mentioning that the year with the lowest total annual rainfall, 2013, also had the lowest percentage of incident rainfall during the rainy season, $71 \%$. Although the total rainfall depth occurring that year was lower, the rainfall occurred more evenly throughout the year (Figure 3D). The opposite was seen in 2008, when the greatest total annual rainfall for the time series occurred, $932 \mathrm{~mm}$. That year presented the highest percentage of incident rainfall during the rainy season, $96 \%$, representing $891 \mathrm{~mm}$.

As for rainfall during the rainy season, Alves, Souza, and Repelli (1998) found that on average during extremely dry seasons, rainfall during the rainy season is less than $40 \%$ of that expected, and changes of more than $-40 \%$ may occur. Further, according to those authors, each year of drought sees a different configuration to the rainfall distribution in the various regions of the State of Ceará, i.e. for each year of drought, different areas of the state are affected by the phenomenon.

There is a strong interannual variability to the rainfall in the region (Figure 3) associated with drought, where the maximum monthly rainfall remained below $100 \mathrm{~mm}$ (Figure 3D). It can also be seen that for March 2008 (Figure 
3C), the total rainfall $(362.71 \mathrm{~mm})$ was close to the annual total $(453.23 \mathrm{~mm})$ for 2013 (Table 4). It should be noted that the rainfall depth in the region during only one month of 2008 , corresponded to almost the total rainfall of 2013, thereby confirming the interannual variability characteristic of the semi-arid region already discussed by Andrade, Meireles and Palácio (2010). Similarly, Polzin and Hastenrath (2014) state that interannual variability in the rainfall regime for the Northeast of Brazil can be understood as changes occurring in the mean annual cycle of the region.

2003

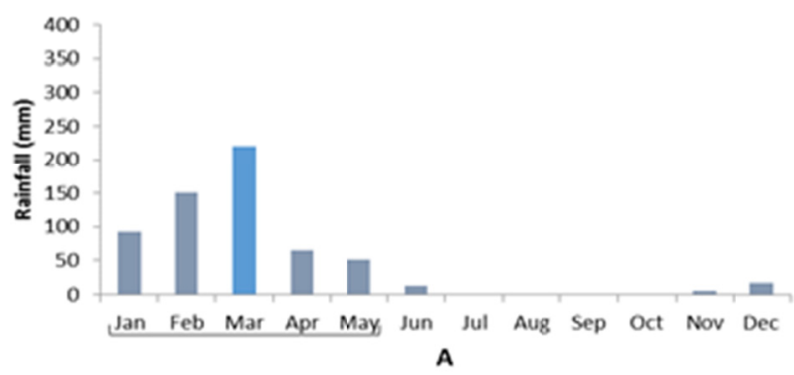

2008

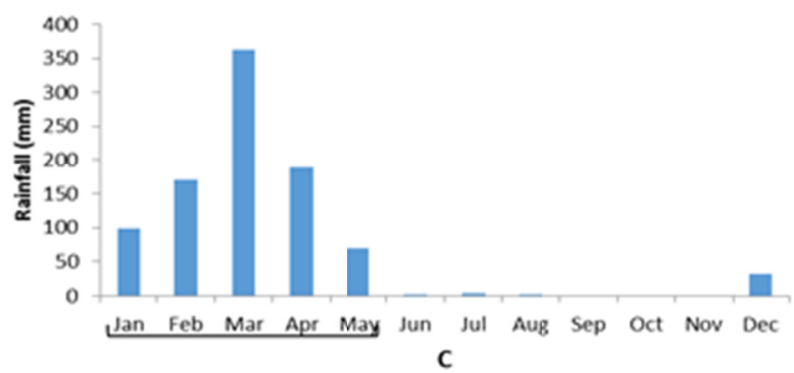

2005
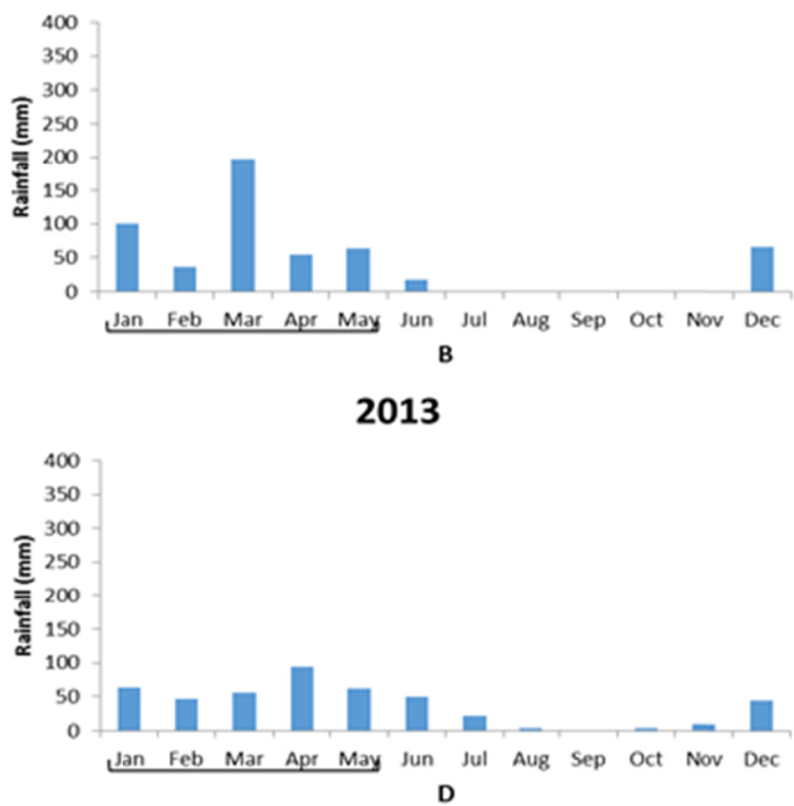

Figure 3. Rainfall graphs for the study period, highlighting the rainy season

Source: Prepared by the author.

Furthermore, in relation to interannual variability seen in semi-arid regions, Sousa, Melo, and Da Silva (2013) found from analysis of the Rainfall Anomaly Index (RAI) for the series under survey (1921 to 2010), that the watershed of the Upper Jaguaribe displayed a larger number of dry years (48 years) in relation to rainy years (40 years). According to the authors, this fact was not very favourable to the maintenance of water resources in the watershed.

\subsection{Land use and Cover in the WSOR}

Processing the Landsat 5 and Landsat 8 images, and application of the MAXVER supervised classification for 2003, 2005, 2008 and 2013, enabled the preparation of four maps of land use and land cover in the WSOR (Figure 4). This information aided study of the behaviour and evolution of the classes used in this research, making it possible to diagnose trends in land use and land cover in the watershed. 


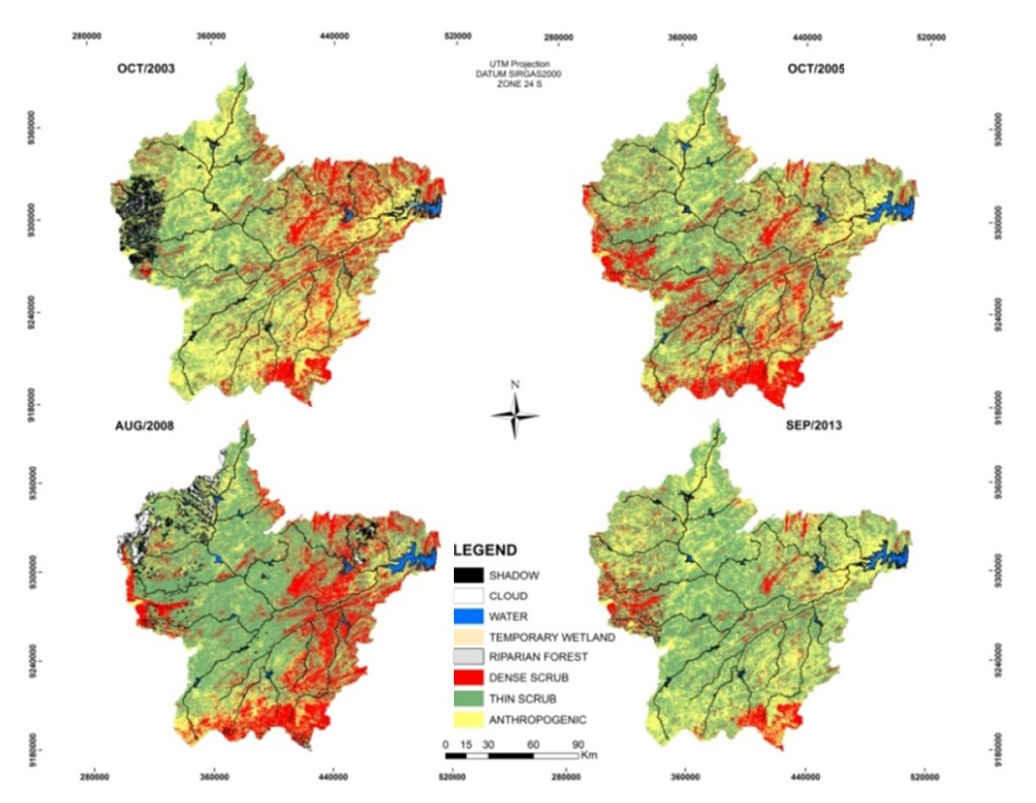

Figure 4. Classification maps of land use and cover in the WSOR

Source: Prepared by the author.

One difficulty was individualising some of the classes, for example, urban areas, exposed soil and rainfed farming. Rainfed farming is very widespread in the semi-arid region of Brazil. The cycle in the region generally begins in the rainy season, when the farmer uses his land to plant short-cycle crops (beans and maize, among others). At the end of the crop cycle, the area is then used as pasture for animals, which consume all the plant material, leaving the soil exposed during the dry season of the year. The spectral response of this type of area is often confused with the spectral response of bare soil and even of an urban area. Hayes and Cohen (2007) state that the occurrence of different changes in land use and cover in any given area results in different patterns of spectral response.

The difficulty in individualising these classes lies in the fact that such types of land use (targets) display very similar spectral behaviour, which makes it difficult to classify them into different classes. Because of this, all such classes mentioned above were grouped into a single class, anthropogenic. In a temporal survey of land-use classes in the basin of the River São Bartolomeu, in the Federal District of Brazil, Ferreira (2006) found that various classes also displayed similar spectral responses, making it difficult to carry out the classification. The author found that the reforestation class was associated with gallery forest, and the urban area and exposed-soil classes were associated with annual farming.

Analysing the data obtained from classifying the images, it can be seen that the predominant classes in the watershed for the study period are the anthropogenic and dense-scrub classes, except in 2008, when the dense-scrub class occupied the second-largest area of the watershed, second only to thin-scrub (Table 4). Concerning the substitution of areas of caatinga vegetation, Vieira et al. (2013), in a survey of land use and cover in the semi-arid region of Brazil, found that $57 \%$ of the Northeast of Brazil represents anthropogenic areas. According to the authors, these areas had been previously occupied, mainly by caatinga, and thereby demonstrate the accelerated degradation of the native vegetation in the region. 
Table 4. Total area $\left(\mathrm{km}^{2}\right)$ and coefficient of variation (\%) for each class of use and land cover in the WSOR

\begin{tabular}{llllll}
\hline & $\mathbf{2 0 0 3}$ & $\mathbf{2 0 0 5}$ & $\mathbf{2 0 0 8}$ & $\mathbf{2 0 1 3}$ & $\mathbf{C V}$ \\
\hline Water & 130.28 & 266.31 & 359.92 & 189.74 & $41.98 \%$ \\
Dense Scrub & $4,340.77$ & $5,075.11$ & $5,362.54$ & $2,026.23$ & $36.00 \%$ \\
Thin Scrub & $9,931.66$ & $11,184.49$ & $12,538.55$ & $13,319.03$ & $12.73 \%$ \\
Anthropogenic & $9,990.33$ & $8,215.90$ & $4,927.23$ & $9,204.09$ & $27.54 \%$ \\
Wetland & 45.42 & 36.53 & 22.97 & 19.85 & $38.27 \%$ \\
Riparian & 120.26 & 122.05 & 180.50 & 88.26 & $30.08 \%$ \\
Cloud & 168.14 & - & 905.22 & 36.27 & $153.11 \%$ \\
Shadow & 173.61 & - & 603.46 & 16.36 & $141.76 \%$ \\
Total $\left(\mathrm{km}^{2}\right)$ & 24,900 & 24,900 & 24,900 & 24,900 & \\
\hline
\end{tabular}

Source: Prepared by the author.

It was found that the classes with the highest CV were those that suffered the greatest influence of the rainfall regime in the region, except for the cloud, shadow and temporary-wetland classes. The interannual variation in total value for the areas of cloud and shadow resulted in the CV of these areas presenting the highest value among all the remaining classes. This happened because these two classes were present during only three of the four years of the study in addition to the large presence of cloud and shadow in 2008, which favoured an increase in $\mathrm{CV}$ for these two classes.

The temporary-wetland class showed a gradual decrease in area for each year under analysis, resulting in the high value seen for $\mathrm{CV}$. The decrease in area in 2008 was expected due to the high rainfall index that year causing the watersheds of the reservoirs to rise, and reducing the area of this class. In 2013, there should have been an increase in area, but the opposite, a decrease, was seen. This class can be considered as the only class that was not directly influenced by the rainfall regime of the watershed, as discussed below.

The dense-scrub class had the lowest value for CV (12.73\%) among all the classes under analysis, suffering the least influence of the rainfall in the watershed during the period analysed. It maintained a trend for constant growth throughout the period analysed, even between one year considered rainy and another considered dry (2008 and 2013 respectively). The opposite was seen for the dense-scrub class, which displayed a greater value for coefficient of variation, $36 \%$. The area of this class was greatly reduced in 2013, a year considered dry, noting that it suffered with the low rainfall in the watershed that year. In addition, Coelho et al. (2014) emphasise that areas of caatinga vegetation can show a progressive substitution by such activities as agriculture or animal farming.

Another class of use and cover in the basin also influenced by the rainfall regime was riparian forest. Again, the influence of two years of extremes in rainfall, 2008 and 2013, can be seen. The rainfall depth in 2008 favoured the recovery of this class of area in the watershed, with the opposite happening in 2013 , the year in which there was a drastic reduction in the area of this class. The degradation suffered by these areas in the watershed of the Upper Jaguaribe should also be taken into account, a fact already verified by Sousa, Melo, and Da Silva (2013), who observed the removal of riparian vegetation in several stretches along the River Jaguaribe, which, according to the authors, can cause silting and erosion of the river margins.

There was a marked drop in the area of the anthropogenic class in 2008, which favoured an increase in its CV value. This reduction in area is due to the response of the vegetation in the watershed to the rains that occurred during that year, which filled the previously exposed soil with vegetation or with types of usage characteristic of the anthropogenic class. In this way, an area previously classified as anthropogenic was classified that year as thin scrub or dense scrub. However, there is strong human pressure on the natural resources of the semi-arid region of the Northeast; thus, Ribeiro et al. (2008) affirm that anthropogenic action has resulted in the continuous degradation of natural resources, causing irreversible damage to the environment of the semi-arid region.

The water class had the third highest coefficient of variation among all the classes of soil use and cover in the watershed, 41.98\%. Comparing the rainfall regime of 2003 and 2013 (Figure 3), it can be seen that even though there was less rainfall in the watershed in 2013 , with $453 \mathrm{~mm}$, this was well distributed throughout the year. In 2003, the total rainfall was $618 \mathrm{~mm}$, tending to increase from January to March, with an abrupt drop from April to June. The dynamics displayed by this class is explained not only by the behaviour of the rainfall in the years of study $(2003,2005,2008$, and 2013), but also in the preceding years. This was because the incident rainfall in 
the watershed during the preceding years influenced a greater recharge of the reservoirs, causing the volume of water stored during the years of the study to reach a higher level.

In 2003, a high value was seen for the anthropogenic class, this being an indication that the WSOR displays a high rate of substitution of native plant composition. Silva, Lima, and Mendonça (2014) carried out a study in the semi-arid region of the Northeast, with the aim of mapping changes in plant cover in the sub-basin of the Espinharas River from 2000 to 2010. Those authors found that most of the sub-basin under study, $80 \%$ of the total, presents marked anthropic activity with highly degraded stretches, showing such areas to be the result of a framework of long-established degradation in the region.

Further in relation to human pressure exerted in areas of caatinga, Silva, Lima, and Mendonça (2014) state that practices such as cutting down vegetation to produce cuttings, charcoal and firewood for domestic or commercial use, and to prepare the area for agriculture, favour a reduction in caatinga vegetation in the semi-arid region. Pereira Filho, Silva, and Cézar (2013), point out that overgrazing by livestock, and itinerant agriculture have been identified as the main factors in the degradation of Caatinga ecosystems.

In relation to the classifications made, and the data obtained, several factors may have acted on the dynamics displayed by the antropogenic, thin-scrub and dense-scrub classes during the study period, these being basic to the behaviour of these classes in 2008. The presence of a large number of clouds in 2008 negatively influenced the total of the anthropogenic class that year, underestimating its total area. In this way, variations in the cloud class from one year to the next can influence certain classes positively or negatively.

Accordingly, the absence of clouds positively influenced the data obtained by Sousa et al. (2007) in a study carried out with the aim of comparing land use and occupation in the watershed of the Upper Piauí during 2004 and 2005 for the rainy and dry season respectively, through satellite image processing. In that study, it was found that the anthropogenic class occupied about $10.8 \%$ of the area of the watershed in 2004 , increasing to $18.1 \%$ in 2005 , showing an increase of $68 \%$. According to the authors, this significant increase occurred due to the images of 2005 being practically free from clouds, contributing to the total of that class. In the above study, the cloud class occupied $18.1 \%$ of the watershed in 2004 against $1.1 \%$ in 2005 .

Another factor worth noting in 2008 is that the total rainfall in the watershed, $932 \mathrm{~mm}$, had a positive influence on the increase of both the thin scrub and dense scrub classes. For the response of vegetation to the rainfall regime in semi-arid regions, Cunha et al. (2012) state that plant cover in dry areas is highly correlated with rainfall. This is the reason for expecting that the years showing a higher rainfall index before passage of the sensor should be exactly those that show a greater increase in plant cover. Further, according to that author, regions with a semi-arid climate have vegetation that is more susceptible to change, responding quickly to the presence or absence of rainfall.

Similarly, Batista and Santos (2011) state that in semi-arid regions, studies of changes in land use and cover using satellite images over fairly short periods, show that seasonality may have a greater influence on changes in classes of land use and cover in a given area, rather than the temporal distance between the years under analysis.

Deciduous vegetation, being one of the main characteristics of the Caatinga, directly influences identification of the classes of land use and cover in semi-arid regions. When this vegetation loses its leaves during the dry season, the soil remains exposed for a certain length of time, altering reflectance values in the band of the electromagnetic spectrum, and displaying the spectral behaviour of bare soil. In this way, an area with a predominance of caatinga vegetation may be classified as exposed soil during the dry season, and be included in the anthropogenic class.

While observing changes in class area between the years of study, Sousa et al. (2007) state that native vegetation consisting of mostly hyperxerophilic caatinga, which has the characteristic of leaf-fall during the dry period, causes these areas to reflect the characteristics of exposed soil in the image, i.e. they may display in a characteristically anthropogenic colour tone.

The inverse can be found in studies such as that of Batista and Santos (2011), who analysed land use and occupation in the town of Teofilândia in the State of Bahia. The authors verified changes to the classes between years, where areas of the exposed-soil class were classified the following year as pasture and caatinga. According to the authors, these changes occurred because the vegetation that was dry and senescent, and previously classified as exposed soil, sprouted and flourished, turning areas of vegetation green, and changing reflectance values due to the action of chlorophyll in the plants.

However, it must be emphasised that areas previously classified as anthropogenic can undergo natural regeneration and later be classified as thin scrub, the opposite also possibly occurring. There is therefore a 
threshold between these two classes, which depending on the pressure they undergo, will result in an exchange of area between them.

It was also found that some remaining areas of the dense-scrub class were still present throughout the study period in regions of high altitude (over 250 metres). Analysing Figure 5, the presence of this class can be seen in the southeastern region of the watershed, even if small in 2013, a year of low total rainfall. The behaviour of this class in elevated areas is therefore influenced not only by the annual rainfall in the watershed, but also by topographical factors.

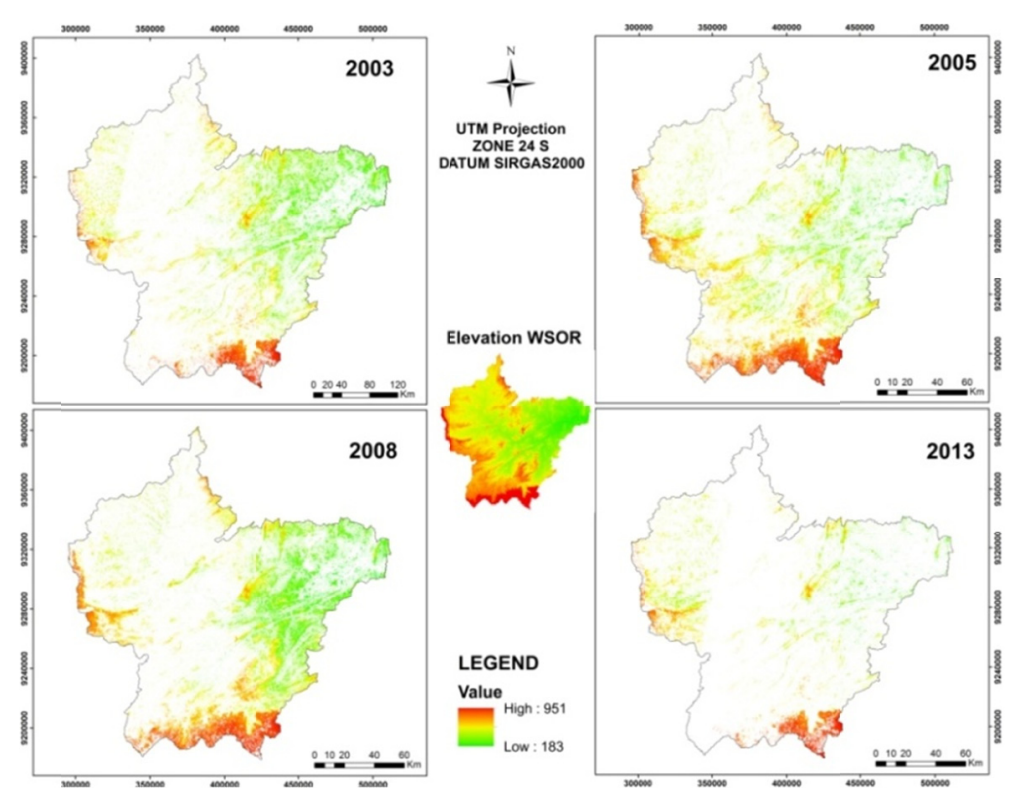

Figure 5. Dense-scrub class in relation to altitude in the WSOR

Source: Prepared by the author.

For the influence that topography has on the vegetation of a given area, Bishop, Valeriano, and Kuplich (2010) verified the connection between certain topographical patterns and some classes of caatinga vegetation in the Serra das Almas Private Reserve, in the State of Ceará. The authors found that some classes were modified by elevation, such as the tree-shrub caatinga and herbaceous-woody caatinga classes, which are restricted to the lowest areas of the reserve. The opposite was seen with the complex tree-like, dry-forest and caatinga-forest classes, which were restricted to the highest altitudes.

In addition to the topographical factors that influence the presence of these classes in high areas, there are other basic factors, such as the limitations that elevation places on anthropogenic action, and the microclimates that exist in these areas. Silva et al. (2014), in a study that aimed to determine the richness and composition of caatinga vegetation in areas at different altitudes in the Brazilian semi-arid region, found that species variety increased with elevation, and that less variety of species was associated with areas of lower elevation, the domain of human action. The authors therefore concluded that two factors are responsible for increasing the diversity of caatinga vegetation at higher altitudes: a reduction in human pressure due to reduced access to these areas, and a larger number of wet microhabitats that favour the development of this vegetation.

Another factor that should be noted in the development of caatinga vegetation in higher regions is the occurrence of orographic rainfall. Such water availability results in the development of vegetation in these regions, and is caused by the orographic arrangement, with mountain ranges and higher plateaus that intercept the wetter fronts receiving more rainfall than their surroundings, and creating leeward areas of little rain (Sampaio, 2010).

The total area destined for riparian forest (APP) according to current legislation, Law 12,651 of 25 May 2012, for rivers and reservoirs rising from the WSOR, is $326.07 \mathrm{~km}^{2}$, which corresponds to $1.31 \%$ of the total area of the watershed. Figure 6 shows the behaviour of the riparian forest throughout the study period. 


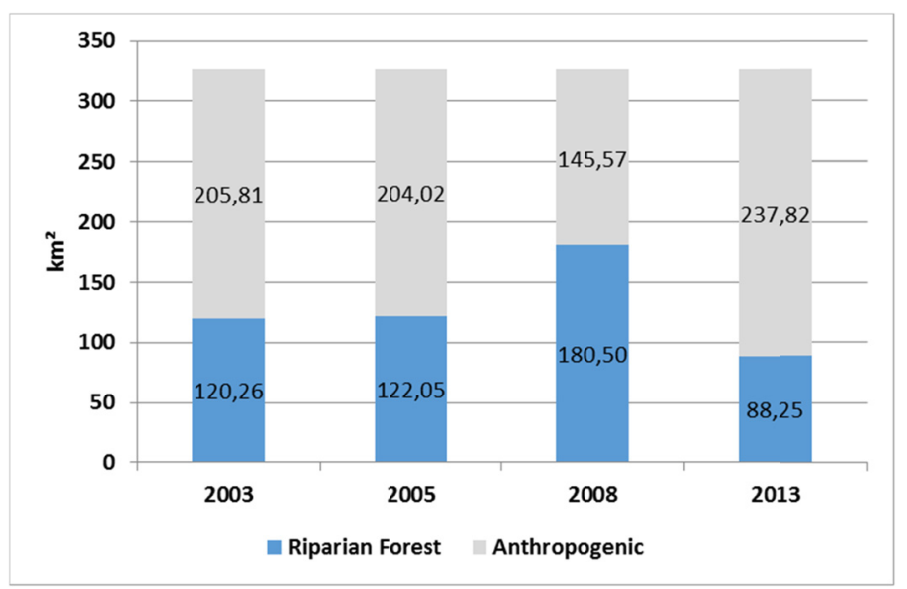

Figure 6. Changes in the area of riparian forest in the WSOR from 2003 to 2013

Source: Prepared by the author.

Based on the data shown, it can be seen that these areas display a high degree of degradation due to suppression of the plant cover. For the years under study, it can be seen that there is a fluctuation in the areas that conform to the legislation in force; however these values are between $88.25 \mathrm{~km}^{2}$ and $180.50 \mathrm{~km}^{2}$ of the total area destined for this class.

Because it is composed of caatinga vegetation, the riparian-forest class displayed the same dynamics identified in the dense-scrub and thin-scrub classes throughout the study period, and was also influenced by the rainfall that occurred in the watershed. It was found that 2008 was the only year in which the vegetation present in this area was greater than the anthropogenic areas of the riparian-forest class, demonstrating the response of the vegetation to the greater rainfall that occurred in the watershed in relation to the other years under study. Another factor that should be considered is the acquisition date of the images. Although they were all obtained (imaged) in the second semester of the years under study, that of 2008 was imaged in August, the closest month to the end of the rainy season in the region (May). The information collected by the Thematic Mapper (TM) sensor for that month was therefore influenced by proximity to the rainy season.

The use of areas of riparian forest for other purposes takes place due to the availability of water in these areas of the watershed, which makes the use of areas near rivers and reservoirs preferred for such human activities as agriculture, livestock and the removal of plants, thereby increasing pressure on the natural resources of these areas.

The efficient role that this vegetation plays in avoiding degradation of the water resources of the watershed should also be noted. For Castelle and Johnson (2000), the rainfall intercepted by the riparian vegetation before contact with the soil surface is more likely to infiltrate or evaporate, reducing surface runoff and consequently the volume and peak runoff of the rainwater. According to the authors, the vegetation also limits erosive processes in these areas, as well as favouring sediment retention.

The two benefits provided by the riparian-forest vegetation, infiltration and sediment retention, are very important in regions with a semi-arid climate. The greater opportunity for infiltration afforded by the vegetation results in greater recharge of the water table in the region, supplying water for a longer period. This effect was seen by Vanzela, Hernandez, and Franco (2010), where they affirm that areas of forest are more protected and stable, with a greater capacity for the infiltration and storage of water in the soil, thus increasing the travel time of the water to the bed of the spring. Over time however, sediment retention reduces the sedimentation of rivers and reservoirs; according to Araújo (2003), in semi-arid regions where the water supply is largely dependent on the surface water accumulated in reservoirs, the average sedimentation rate of these infrastructures is $1.85 \%$ each decade.

Queiroz et al. (2010), in a study to verify the influence of land use on water quality in the Sanga Mandarina watershed in Cascavel in the State of Paraná, recognised the importance of preserving the riparian forest, since according to the authors, the vegetation reduces and filters surface runoff, preventing or minimising entrainment of sediments and nutrients into the water system, thereby helping to maintain the quality and quantity of the water in the watersheds. 
With regard to the temporary-wetland class, an analysis of Figure 7 shows a trend to reduce the area where this practice is carried out each year in the watershed.

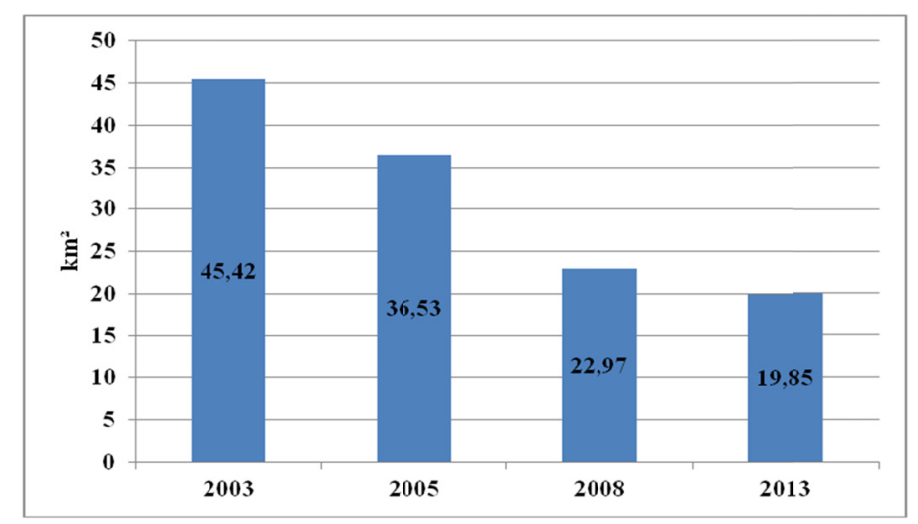

Figure 7. Total area of the temporary-wetland class for each year of the study period

Source: Prepared by the author.

The dynamics presented by the areas of temporary wetland would seem to be related to the occurrence of rainfall in the region, where years of high rainfall should consequently decrease the area of this class due to recharge of the reservoirs, thereby increasing the size of the watershed. However, during the period under analysis, there is a downward trend to carrying out this practice in the watershed, even in dry years. During dry years, the reduction in areas of temporary wetland is linked to the higher production costs resulting from the lower levels of the reservoir, resulting in an increase in the costs of pumping water (pumps, pipes, energy, etc.).

Another factor concerns water quality in the reservoir, where in dry years there is a reduction in quality. This problem was seen by Meireles, Frischkorn and Andrade (2007) in a study to evaluate the water dynamics of the Edson Queiroz reservoir in Santa Quiteria, Ceará. The authors found that an increase in salt concentrations as measured by electrical conductivity (EC) and of chlorides $\left(\mathrm{Cl}^{-}\right)$corresponded to reductions in the volume of the reservoir.

To explain the trend towards a reduction in the area of temporary wetland in the watershed, a survey was taken of the total population of the cities inserted in the watershed (26 in total) for 2000-2010 (Figure 8). There was a reduction found in the resident population of the rural areas of these cities, with an increase in the resident population of the urban areas. This fact explains the decrease in wetland activity as being due to the smaller workforce found in rural areas, where wetland activity in the watershed is generally carried out.

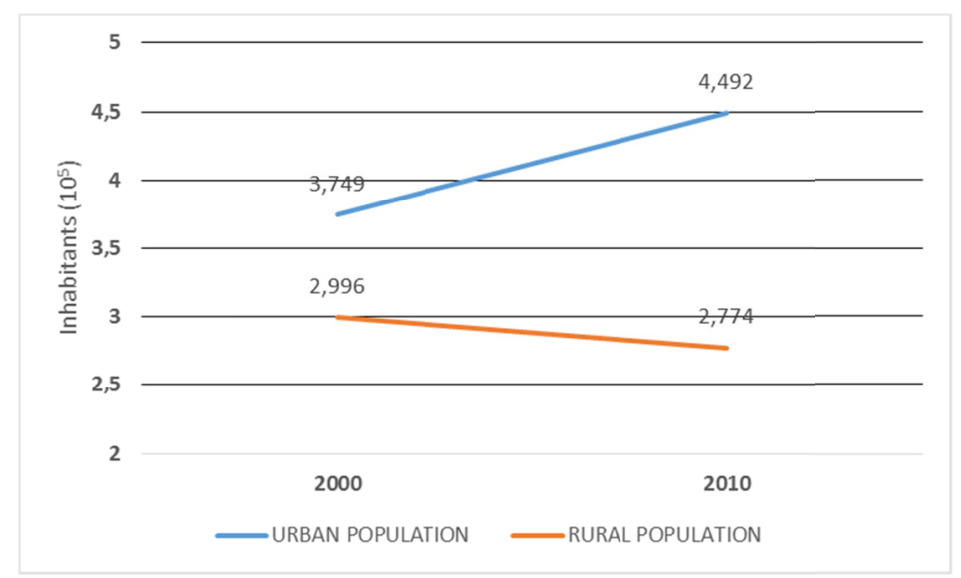

Figure 8. Behaviour of urban and rural populations in the WSOR for 2000-2010

Source: Prepared by the author based on data from the Statistical Yearbook of Ceará, 2013 (IPECE, 2013). 
Although the above factors may be related to decreases in the area of the wetland class during the study period, it should also be pointed out that this trend may be related to gradual abandonment and the lack of interest on the part of producers to continue this practice. Other more profitable and less laborious activities or even government aid may be helping to reduce this practice in the WSOR over time.

\subsection{Accuracy of the Classifications}

The confusion matrix to evaluate the accuracy of each classification was generated by the ENVI 4.7 software from the Regions of Interest (ROI) defined during the image classification stage, the result being the accuracy and Kappa index. Table 5 shows the values for accuracy and Kappa index obtained for the classification of the 4 years (4 images) used in this study.

Table 5. Values for Accuracy and Kappa Index obtained with the classifications

\begin{tabular}{lll}
\hline Year & Accuracy (\%) & KAPPA Index \\
\hline 2003 & $95.69 \%$ & 0.9390 \\
2005 & $98.81 \%$ & 0.9819 \\
2008 & $99.15 \%$ & 0.9804 \\
2013 & $99.71 \%$ & 0.9943 \\
\hline
\end{tabular}

Source: Prepared by the author.

The values for accuracy show that between $95.69 \%$ and $99.71 \%$ of pixels were classified correctly. All the classifications made were considered excellent according to the Landis and Koch (1977) classification, as the values for the Kappa index were within the range of 0.8 to 1.

\section{Conclusion}

The climatic seasonality in the watershed had a direct influence on the classes of use and cover. Higher rainfall in the watershed favoured an increase in the thin-scrub and dense-scrub classes, the opposite being seen in the areas of the anthropogenic class.

The changes that took place during the period under analysis are not only the result of human intervention in the environment, but also of climatic factors. The time the images were generated should be taken into account, so that the influence of the climate on image classification is avoided or reduced.

Land use in the region was seen to be inadequate, considering the high degree of degradation of the areas of riparian forest in the watershed.

\section{References}

Alves, J. M. B., Souza, E. B., \& RepellI, C. A. (1998). Principais secas ocorridas nesse século no Estado do Ceará: uma avaliação pluviométrica. X Congresso Brasileiro de Meteorologia. Anais... Brasilia: CBM.

Andrade, E. M., Meireles, A. C. M., \& Palácio, H. de A. Q. (2010). O semiárido cearense e suas águas. In E. M. Andrade, O. J. Pereira, \& F. E. R. Dantas (Org.), O SEMIÁRIDO e o manejo dos recursos naturais (pp. 71-94). Fortaleza: Imprensa Universitária-UFC.

Antunes, M. A. H., Freire, R. M. B., Botelho, A. S., \& Toniolli, L. H. (2003). Correções atmosféricas de imagens de satélites utilizando o modelo $6 S$ (p. 6). Congresso Brasileiro de Cartografia, 21. Anais... Belo Horizonte: CBC.

Araújo, J. C. (2003). Assoreamento em Reservatórios do Semiárido: Modelagem e Validação. Revista Brasileira de Recursos Hídricos, 8(2), 39-56. https://doi.org/10.21168/rbrh.v8n2.p39-56

Batista, J. L. O., \& Santos, R. L. (2011). Análise da dinâmica do uso e ocupação da terra em pequenos municípios baianos do semi-árido brasileiro: o caso de Teofilândia. Revista de Geografia Norte Grande, 49, 139-155. https://doi.org/10.4067/S0718-34022011000200009

Batista, J. L. O., \& Santos, R. L. (2013). A caracterização do uso e ocupação do solo de uma zona semiárida entre 1993 a 2008 através da classificação supervisionada Maxver: O caso do município de Teofilândia, Bahia (BA)-Brasil. Revista Geográfica Venezolana, 54(1), 99-111. 
Bertossi, A. P. A., Cecílio, R. A., Neves, M. A., \& Garcia, G. O. (2013). Qualidade da água em microbacias hidrográficas com diferentes coberturas do solo no sul do Espírito Santo. Revista Árvore, 37(1). https://doi.org/10.1590/S0100-67622013000100012

Bispo, P. C., Valeriano, M. M., \& Kuplich, T. M. (2010). Relação da vegetação de caatinga com a condição geomorfométrica local. Revista Brasileira de Engenharia Agrícola e Ambiental, 14(5). https://doi.org/ $10.1590 / \mathrm{S} 1415-43662010000500010$

Castelle, A. J., \& Johnson, A. W. (2000). Riparian vegetation effectiveness. Technical Bulletin of the National Council for Air and Stream Improvement, 799, 26.

Coelho, V. H. R., Montenegro, S. M. G. L., Almeida, C. N., Lima, E. R. V., Neto, A. R., \& Moura, G. S. S. (2014). Dinâmica do uso e ocupação do solo em uma bacia hidrográfica do semiárido brasileiro. Revista Brasileira de Engenharia Agrícola e Ambiental, 18(1). https://doi.org/10.1590/S1415-43662014000100009

COGERH (Companhia de Gestão dos Recursos Hídricos). (2015). Sistema de Apoio ao Gerenciamento dos Recursos Hídricos (SAGREH 2015)—Ficha Técnica Açude Orós.

Cunha, J. E. B. L., Rufino, I. A. A., Da Silva, B. B., \& Chaves, I. B. (2012). Dinâmica da cobertura vegetal para a Bacia de São João do Rio do Peixe, PB, utilizando-se sensoriamento remoto. Revista Brasileira de Engenharia Agrícola e Ambiental, 16(5). https://doi.org/10.1590/S1415-43662012000500010

Ferreira, C. S. (2006). Avaliação Temporal do Uso e Ocupação das Terras na Porção Setentrional da Bacia Hidrográfica do São Bartolomeu (131 f. Dissertação (Mestrado em Ciências Agrárias), Universidade de Brasília, Brasília).

Frota, P. V. (2012). Potencial de Erosão na Bacia de Drenagem do Açude Orós-CE (179 f. Thesis (PhD in Forestry Sciences), University of Brasília, Brasília).

Galharte, C. A., Villela, J. M., \& Crestana, S. (2014). Estimativa da produção de sedimentos em função da mudança de uso e cobertura do solo. Revista brasileira de engenharia agrícola e ambiental, 18(2). https://doi.org/10.1590/S1415-43662014000200010

Hayes, D. J., \& Cohen, W. B. (2007). Spatial, spectral and temporal patterns of tropical forest cover change as observed with multiple scales of optical satellite data. Remote Sensing of Environment, 106, 1-16. https://doi.org/10.1016/j.rse.2006.07.002

INPE (Instituto Nacional de Pesquisas Espaciais). (2014). Retrieved from http://www.dgi.inpe.br/siteDgi/ ATUS_LandSat.php

IPECE (Instituto de Pesquisa e Estratégia Econômica do Ceará). (2013). Anuário Estatístico do Ceará 2013. Retrieved from http://www2.ipece.ce.gov.br/publicacoes/anuario/anuario2013/demografia/populacao.htm

Landis, J. R., \& Koch, G. C. (1977). The measurement of observer agreement for categorical data. Biometrics, 33(1), 159-14. https://doi.org/10.2307/2529310

Lopes, F. B. (2013). Uso de sensoriamento remoto como suporte ao monitoramento da qualidade das águas superficiais da região semiárida do Brasil (202 f. Tese (Doutorado em Engenharia Agrícola), Universidade Federal do Ceará, Fortaleza).

Meireles, A. C. M., Frischkorn, H., \& Andrade, E. M. (2007). Sazonalidade da qualidade das águas do açude Edson Queiroz, bacia do Acaraú, no Semiárido cearense. Revista Ciência Agronômica, 38(1).

Montanher, O. C., \& Paulo, M. C. M. (2014). X-6SCORR: Conversão semi-automática de ND de imagens orbitais para FRB baseada em metadados XML e código 6S. Revista Brasileira de Cartografia, 66, 223-231.

Pereira Filho, J. M., Silva, A. M. A., \& Cézar, M. F. (2013). Manejo da Caatinga para produção de caprinos e ovinos. Revista Brasileira de Saúde e Produção Animal, 14(1), 77-90. https://doi.org/10.1590/S1519 $-99402013000100010$

Polzin, D., \& Hastenrath, S. (2014). Climate of Brazil's nordeste and tropical atlantic sector: preferred time scales of variability. Revista Brasileira de Meteorologia, 29(2), 153-160. https://doi.org/10.1590/S0102-778 62014000200001

Queiroz, M. M. F. de, Iost, C., Gomes, S. D., \& Vilas Boas, M. A. (2010). Influência do uso do solo na qualidade da água de uma microbacia hidrográfica rural. Revista Verde de Agroecologia e Desenvolvimento Sustentável, 5(4), 200-210. 
Ribeiro, G. N., Teotia, H. S., Maracaja, V. P. B. B., \& Barros, D. F. (2008). Mapeamento do uso da terra e cobertura vegetal no agreste Paraibano: Municípios de Pocinhos e Puxinanã. Revista Caatinga, 21(2), 231-244.

Sampaio, E. V. S. B. (2010). Caracteristicas e potencialidades. In M. A. Gariglio, E. V. S. B. Sampaio, L. A. Cestaro, \& P. Y. Kageyama (Eds.), Uso sustentável e conservação dos recursos florestais da caatinga (pp. 29-48). Brasília: Serviço Florestal Brasileiro.

Silva, R. M., Silva, L. P., Montenegro, S. M. G. L., \& Santos, C. A. G. (2010). Análise da variabilidade espaço-temporal e identificação do padrão da precipitação na bacia do rio Tapacurá, Pernambuco. Sociedade \& Natureza, 22(2), 357-37. https://doi.org/10.1590/S1982-45132010000200010

Silva, F. K. G., Lopes, S. F., Lopez, L. C. S., Melo, J. I. M., \& Trovão, D. M. B. M. (2014). Patterns of species richness and conservation in the Caatinga along elevational gradients in a semiarid ecosystem. Journal of Arid Environments, 110, 47-52. https://doi.org/10.1016/j.jaridenv.2014.05.011

Silva, R. M. P., Lima, J. R., \& Mendonca, I. F. C. de. (2014). Alteração da cobertura vegetal na Sub-Bacia do Rio Espinharas de 2000 a 2010. Revista Brasiselira de Engenharia Agrícola e Ambiental, 18(2). https://doi.org/ $10.1590 /$ S1415 -43662014000200011

Sousa, A. B., Melo, R. A., \& Da Silva, D. F. (2013). Avaliação climática e dos recursos hídricos da bacia hidrográfica do rio Jaguaribe (CE). Revista Brasileira de Geografia Física, 6, 1115-1140.

Sousa, B. F. S., Teixeira, A. S., Leão, R. A. O., \& Costa Filho, A. B. (2007). Uso do solo da bacia hidrográfica do Alto Piauí através de imagens do satélite CBERS. Revista Ciência Agronômica, 38, 327-334.

Toledo, C. E. (2013). Conectividade hidrológica em ambiente semiárido: Estudo de caso Bacia Hidrográfica do Açude Orós (136 f. Tese (Doutorado em Engenharia Agrícola), Universidade Federal do Ceará, Fortaleza).

Vanzela, L. S., Hernandez, F. B. T., \& Franco, R. A. M. (2010). Influência do uso e ocupação do solo nos recursos hídricos do Córrego Três Barras, Marinópolis. Revista Brasileira de Engenharia Agrícola e Ambiental, 14(1). https://doi.org/10.1590/S1415-43662010000100008

Verbesselt, J., Hyndman, R., Newnham, G., \& Culvenor, D. (2010). Detecting trend and seasonal changes in satellite image time series. Remote Sensing of Environment, 114, 106-115. https://doi.org/10.1016/j.rse. 2010.08.003

Vieira, R. M. S. P., Cunha, A. P. M. A., Alvalá, R. C. S., Carvalho, V. C., Neto, S. F., \& Sestini, M. F. (2013). Land use and land cover map of a semiarid region of Brazil for meteorological and climatic models. Revista Brasileira de Meteorologia, 28(2). https://doi.org/10.1590/S0102-77862013000200002

\section{Copyrights}

Copyright for this article is retained by the author(s), with first publication rights granted to the journal.

This is an open-access article distributed under the terms and conditions of the Creative Commons Attribution license (http://creativecommons.org/licenses/by/4.0/). 